\title{
PENGARUH ION Cr(VI) PADA VARIASI PH TERHADAP SERAPAN ION Cu(II) OLEH ADSORBEN KULIT KACANG TANAH DENGAN SPEKTROFOTOMETRI SERAPAN ATOM
}

\author{
Devi Puriyandari ${ }^{* *}$, Pandu J. Laksono $\left.{ }^{2 * *}\right)$ \\ ${ }^{1}$ Universitas Sebelas Maret Surakarta \\ ${ }^{2}$ Universitas Islam Negeri Raden Fatah Palembang \\ ${ }^{*}$ E-mail: devipuriyandari3@gmail.com \\ **) E-mail: pandujati_uin@radenfatah.ac.id
}

\begin{abstract}
Abstrak: Penelitian ini bertujuan untuk mengetahui: (1) pemanfaatan limbah kulit kacang tanah sebagai adsorben logam berat $\mathrm{Cu}(\mathrm{II})$, (2) hubungan $\mathrm{pH}$ terhadap adsorpsi logam $\mathrm{Cu}(\mathrm{II})$, (3) pengaruh penambahan ion logam $\mathrm{Cr}(\mathrm{VI})$ terhadap serapan logam $\mathrm{Cu}(\mathrm{II})$ pada variasi $\mathrm{pH}$ oleh kulit kacang tanah, (4) pola isoterm dan jenis adsorbsi yang terjadi pada penyerapan ion logam $\mathrm{Cu}(\mathrm{II})$ dengan dan tanpa penambahan ion logam Cr(VI) oleh adsorben kulit kacang tanah. Penelitian dilakukan dengan metode eksperimen. Teknik pengumpulan data meliputi: (1) pembuatan adsorben dari kulit kacang tanah, (2) karakterisasi gugus yang terkandung dalam kulit kacang tanah dengan FTIR, (3) aplikasi adsorben untuk mengetahui pengaruh penambahan ion logam $\mathrm{Cr}(\mathrm{VI})$ terhadap serapan $\mathrm{Cu}(\mathrm{II})$ melalui pengontakkan 0,5 gram kulit kacang tanah dengan $25 \mathrm{~mL}$ larutan logam $\mathrm{Cu}$ (II) $50 \mathrm{ppm}$ dan campuran logam $\mathrm{Cu}(\mathrm{II}) 50$ ppm dengan $\mathrm{Cr}$ (VI) 50 ppm pada variasi $\mathrm{pH} \mathrm{2;} \mathrm{3;} \mathrm{4;} \mathrm{5;} \mathrm{dan} 6$ selama 60 menit, (4) penentuan konsentrasi logam $\mathrm{Cu}$ (II) yang terserap dengan Spektrofotometri Serapan Atom. Hasil penelitian menunjukkan: (1) kulit kacang tanah dapat digunakan sebagai adsorben ion logam $\mathrm{Cu}(\mathrm{II})$, (2) semakin besar $\mathrm{pH}$ daya serap kulit kacang terhadap logam $\mathrm{Cu}(\mathrm{II})$ semakin meningkat, daya serap terbesar pada $\mathrm{pH} 6$ yaitu sebesar 94,836\%, (3) pada $\mathrm{pH}$ diatas 3,5 penambahan ion logam $\mathrm{Cr}(\mathrm{VI})$ memperbesar daya serap kulit kacang tanah terhadap logam $\mathrm{Cu}(\mathrm{II})$, sedangkan pada $\mathrm{pH}$ dibawah 3,5 cenderung memperkecil daya serap adsorben terhadap $\mathrm{Cu}(\mathrm{II})$, daya adsorpsi terbesar pada $\mathrm{pH} 6$ yaitu sebesar 99,864\%, (4) jenis adsorbsi oleh kulit kacang tanah yang terjadi untuk variasi $\mathrm{pH}$ tanpa penambahan ion logam $\mathrm{Cr}(\mathrm{VI})$ adalah adsorbsi kimia, sedangkan jenis adsorbsi untuk variasi $\mathrm{pH}$ dengan penambahan ion logam $\mathrm{Cr}(\mathrm{VI})$ adalah adsorpsi fisika.
\end{abstract}

Kata kunci: adsorben, ion logam $\mathrm{Cr}(\mathrm{VI})$, ion logam $\mathrm{Cu}(\mathrm{II})$, karakterisasi, kulit kacang tanah

\section{PENDAHULUAN}

Sektor industri merupakan salah satu sektor pembangunan yang berkembang pesat di Indonesia. Perkembangan pada sektor ini tentu saja akan diikuti dengan bertambahnya pencemaran lingkungan yang disebabkan oleh limbah, terutama pencemaran pada lingkungan perairan, karena pada umumnya limbah cair industri dibuang langsung ke selokan atau sungai. Pencemaran air dapat berupa bau yang tidak sedap, warna keruh atau tidak jernih sebagai akibat adanya senyawa organik didalamya. Sedangkan pencemaran air akibat adanya logam berat akan memberikan dampak negatif bagi ekosistem serta lingkungan sekitar, namun dampak ini akan terlihat dalam jangka waktu yang cukup lama yakni ketika logam-logam tersebut sudah terakumulasi dalam jumlah tertentu atau 
melebihi ambang batas, sehingga kualitas air akan mengalami penurunan yang mengakibatkan minimnya air bersih yang dapat digunakan.

Logam berat apabila masuk ke perairan sangat berbahaya, hal ini disebabkan oleh sifat-sifat logam berat yaitu:

1. sulit didegradasi, sehingga mudah terakumulasi dalam lingkungan perairan dan keberadaannya secara alami sulit terurai (dihilangkan).

2. dapat terakumulasi dalam organisme termasuk kerang dan ikan, dan akan membahayakan kesehatan manusia yang mengkonsumsi organisme tersebut.

3. mudah terakumulasi di sedimen, sehingga konsentrasinya selalu lebih tinggi dari konsentrasi logam dalam air. Disamping itu sedimen mudah tersuspensi karena pergerakan masa air yang akan melarutkan kembali logam yang dikandungnya ke dalam air, sehingga sedimen menjadi sumber pencemar potensial dalam skala waktu tertentu (Sutamihardja, Adnan, \& Sanusi, 1982).

Cuprum atau tembaga $(\mathrm{Cu})$ merupakan salah satu logam yang banyak terdapat dalam limbah cair yang merupakan logam berbahaya bagi kesehatan apabila telah masuk ke dalam tubuh manusia melebihi ambang batas. Tembaga yang masuk ke dalam tatanan lingkungan perairan dapat berasal dari peristiwaperistiwa alamiah dan sebagai efek samping dari aktivitas yang dilakukan oleh manusia seperti buangan industri dan pertambangan $\mathrm{Cu}$. Secara alamiah, $\mathrm{Cu}$ masuk ke dalam badan perairan sebagai akibat dari peristiwa erosi atau pengikisan batuan mineral dan melalui persenyawaan $\mathrm{Cu}$ di atmosfer yang dibawa turun oleh air hujan. Melalui jalur alamiah ini, $\mathrm{Cu}$ yang masuk ke badan perairan diperkirakan mencapai 325.000 ton per tahun.

Keberadaan $\mathrm{Cu}$ di lingkungan perlu mendapat perhatian mengingat kecilnya batas konsentrasi yang diijinkan. Berdasarkan Peraturan Daerah Provinsi Jawa Tengah Nomor 5 Tahun 2012 Tentang Baku Mutu Air Limbah keberadaan $\mathrm{Cu}$ dalam lingkungan diharapkan nihil, sedangkan batas maksimal yang diperbolehkan adalah 2,0 $\mathrm{mg} / \mathrm{L}$. Oleh karena itu kandungan logam berat khususnya $\mathrm{Cu}$ dalam limbah industri yang melebihi ambang batas harus diminimalkan sebelum dibuang ke lingkungan. Sehingga untuk mengolah limbah cair yang dihasilkan memerlukan suatu proses yang ramah lingkungan. maka perlu dilakukan penelitian untuk mengurangi kandungan logam berat dalam limbah industri.

Penelitian-penelitian yang dilakukan berkenaan dengan daya racun yang dimiliki oleh $\mathrm{Cu}$ (II) telah dilakukan oleh banyak lembaga ataupun perorangan. Beberapa penelitian menunjukkan bahwa daya racun yang dimiliki oleh $\mathrm{Cu}$ dapat membunuh biota perairan, yang sangat peka terhadap kelebihan $\mathrm{Cu}$ dalam badan perairan tempat hidupnya. Konsentrasi $\mathrm{Cu}$ terlarut yang mencapai 0,01 ppm akan mengakibatkan kematian bagi fitoplankton. Kematian tersebut disebabkan karena daya racun $\mathrm{Cu}$ telah menghambat aktivitas enzim dalam pembelahan sel fitoplankton (Palar, 1994).

Pada umumnya proses yang dilakukan untuk mengurangi limbah cair diantaranya melalui proses pengendapan, pertukaran ion, evaporasi, elektrodialisis, penghilangan warna serta adsorpsi. Proses-proses tersebut biasanya menghabiskan biaya yang relatif tinggi, sehingga tidak cocok untuk kebutuhan negara yang sedang berkembang, seperti Indonesia. Adsorpsi merupakan metode 
yang dinilai paling efektif dan telah banyak digunakan (Cahyono \& Damayanti, 2007).

Proses penanganan limbah cair yang telah tercemar logam berat melalui adsorpsi mempunyai banyak keuntungan, yaitu cukup selektif, efektif, dan dapat mengurangi kadar logam berat yang terlarut dalam limbah cair. Salah satu adsorben dari bahan alam yang dapat digunakan adalah kulit kacang tanah, telah dilakukan beberapa penelitian menggunakan kulit kacang tanah sebagai biosorben, seperti penelitian yang telah dilakukan oleh Periasamy, Srinivasan, \& Murugan (1993) mengenai studi pengurangan logam chromium (VI) dengan menggunakan karbon aktif dari kulit kacang dengan daya adsorpsi $30.21 \pm 0.74$ $\mathrm{mg} \mathrm{g}^{-1}$.

Daya adsorpsi adsorben terhadap logam dipengaruhi oleh beberapa faktor diantaranya adalah derajat keasaman $(\mathrm{pH})$ dan keterlibatan ion lain dalam limbah cair seperti pada penelitian yang telah dilakukan oleh (Johnson, Jain, Joshi, \& Prasad, 2008) dengan beberapa limbah hasil pertanian sebagai adsorben beberapa logam berat antara lain $\mathrm{Cd}(\mathrm{II}), \mathrm{Cr}, \mathrm{Cu}(\mathrm{II}), \mathrm{Ni}(\mathrm{II}), \mathrm{Zn}(\mathrm{II})$, dan $\mathrm{Pb}$ (II). Hasil penelitian menunjukkan bahwa logam yang dapat terserap oleh adsorben dari kulit kacang tanah adalah $\mathrm{Cd}(\mathrm{II}), \mathrm{Cu}(\mathrm{II}), \mathrm{Ni}(\mathrm{II})$, dan $\mathrm{Zn}$ (II). Daya adsorpsi untuk masing-masing logam sebesar: $\mathrm{Cd}(\mathrm{II})=5,96 \mathrm{mg} / \mathrm{g} ; \mathrm{Cu}(\mathrm{II})=65,6 \mathrm{mg} / \mathrm{g}$ pada $\mathrm{pH}$ 610; dan $\mathrm{Ni}(\mathrm{II})=53,65 \mathrm{mg} / \mathrm{g}$ pada $\mathrm{pH} 4-5 ; \mathrm{Zn}(\mathrm{II})=9 \mathrm{mg} / \mathrm{g}$. Dari hasil penelitian dapat disimpulkan bahwa daya adsorpsi terbesar adalah pada logam $\mathrm{Cu}(\mathrm{II})$. Penelitian yang telah dilakukan oleh Saleh(2011) mengenai karakteristik dan pengaruh ion $\mathrm{Ca}^{2+}$ pada adsorpsi ion bikromat oleh humin, memberikan hasil bahwa ion $\mathrm{Ca}^{2+}$ dapat memperbesar daya serap humin terhadap ion bikromat. Pada penelitian ini ion $\mathrm{Ca}^{2+}$ berfungsi sebagai penjembatan kation untuk memperbesar kapasitas adsorpsi terhadap ion bikromat.Penelitian-penelitian di atas telah mendukung dan menjadi landasan untuk melaksanakan penelitian selanjutnya mengenai pemanfaatan serbuk kulit kacang tanah.

\section{METODE PENELITIAN}

Sampel yang digunakan adalah limbah kulit kacang tanah yang diambil dari industri penggilingan kacang tanah di desa Banaran, Palur, Kabupaten Karanganyar. Prosedur penelitian adalah sebagai berikut ini :

\section{Prosedur Penelitian}

1. Preparasi Adsorben Dari Kulit Kacang Tanah

Mencuci kulit kacang tanah dengan air mengalir sampai bersih, yaitu sampai air bilasan tidak keruh lagi, merendam kulit kacang tanah dengan aquades, $\mathrm{NaOH}$ 0,1 $\mathrm{M}$ dan kemudian $\mathrm{CH}_{3} \mathrm{COOH}$ 0,1 $\mathrm{M}$ untuk menetralkan serbuk kulit kacang tanah, cuci dengan aquades sampai bersih/tidak berwarna, mengeringkan kulit kacang tanah di dalam oven pada suhu $60^{\circ} \mathrm{C}$, menghaluskan kulit kacang tanah dengan crusher dan blender, mengayak serbuk kulit kacang tanah yang telah kering dengan ayakan mesh ukuran 200 mesh dan 100 mesh, menganalisis struktur adsorben kulit kacang tanah dengan FTIR.

2. Pembuatan Larutan $\mathrm{Cu}(\mathrm{II}) 50 \mathrm{ppm}$ 
Mengambil $5 \mathrm{~mL}$ larutan induk $\mathrm{Cu}(\mathrm{II}) 1000 \mathrm{ppm}$, memasukkan dalam labu ukur $100 \mathrm{~mL}$ kemudian menambahkan larutan $\mathrm{HNO}_{3}$ 0,05 M sampai tanda batas.

3. Pembuatan Larutan Standar Cu(II) dengan Konsentrasi 0,5; 1; 2; 3; 4; 6 ppm Mengencerkan larutan $\mathrm{Cu}$ (II) 50 ppm menjadi larutan standar $\mathrm{Cu}$ (II) $6 \mathrm{ppm}$ dengan cara mengambil $3 \mathrm{~mL}$ larutan $\mathrm{Cu}$ (II) 50 ppm, memasukkan ke dalam labu ukur $25 \mathrm{~mL}$, dan menambahkan $\mathrm{HNO}_{3}$ 0,05 $\mathrm{M}$ sampai tanda batas, mengulangi pengenceran larutan $\mathrm{Cu}$ (II) 50 ppm sehingga menjadi larutan standar $\mathrm{Cu}$ (II) $4 ; 3 ; 2 ; 1$ dan 0,5 ppm dengan cara yang sama, mengukur absorbansi larutan standar tersebut dengan menggunakan Spektrofotometri Serapan Atom (SSA) untuk mendapatkan kurva kalibrasi.

4. Pembuatan Larutan Induk Cr(VI) 1000 ppm

Menimbang 0,283 gram $\mathrm{K}_{2} \mathrm{Cr}_{2} \mathrm{O}_{7}$, memasukkan dalam labu ukur $100 \mathrm{~mL}$ kemudian menambahkan akuades sampai tanda batas.

5. Pembuatan Larutan $\mathrm{Cu}($ II) 50 ppm pH $2 ; 3 ; 4 ; 5 ; 6$

Memasukkan 2,5 mL larutan induk 1000 ppm ke dalam labu ukur $50 \mathrm{~mL}$, menambahkan akuades, $\mathrm{HNO}_{3} 0,05 \mathrm{M}$ atau $\mathrm{NaOH}$ 0,05 $\mathrm{M}$ sampai tanda batas dan $\mathrm{pH}$ larutan menjadi 2, membagi larutan tersebut menjadi dua, sebagai larutan awal dan sebagai larutan yang akan dikontakkan, mengulangi hal yang sama untuk mendapatkan larutan $\mathrm{Cu}(\mathrm{II}) 50$ ppm pH 3; 4; 5; 6.

6. Pembuatan Larutan $\mathrm{Cu}(\mathrm{II})$ dan $\mathrm{Cr}(\mathrm{VI}) 50$ ppm pH 2; 3; $4 ; 5 ; 6$

Mencampurkan 2,5 mL larutan induk Cu(II) $1000 \mathrm{ppm}$ dan 2,5 mL larutan induk $\mathrm{Cr}$ (VI) $1000 \mathrm{ppm}$ ke dalam labu ukur $50 \mathrm{~mL}$, menambahkan aquades, $\mathrm{HNO}_{3} 0,05 \mathrm{M}$ atau $\mathrm{NaOH} 0,05 \mathrm{M}$ sampai $\mathrm{pH}$ larutan menjadi 2, membagi larutan tersebut menjadi dua, sebagai larutan awal dan sebagai larutan yang akan dikontakkan, mengulangi hal yang sama untuk mendapatkan larutan $\mathrm{Cu}(\mathrm{II}) 50$ ppm pH $3 ; 4 ; 5 ; 6$.

7. Penentuan Pengaruh $\mathrm{pH}$ terhadap Serapan Logam $\mathrm{Cu}(\mathrm{II})$ oleh Serbuk Kulit Kacang Tanah

Menimbang 0,5 gram adsorben serbuk kulit kacang tanah dengan neraca analitik, memasukkan adsorben ke dalam labu Erlenmeyer yang berisi $25 \mathrm{~mL}$ larutan $\mathrm{Cu}$ (II) $50 \mathrm{ppm}$ dengan $\mathrm{pH}$ 2, lalu menutup rapat, mengaduk dengan shaker selama 60 menit dengan kecepatan $125 \mathrm{rpm}$, menyaring masingmasing campuran yang telah dishaker menggunakan kertas saring Whatmann 42 dan mengukur absorbansi filtrat tersebut dengan menggunakan Spektrofotometri Serapan Atom (SSA). melakukan hal yang sama seperti di atas untuk larutan $\mathrm{Cu}$ (II) 50 ppm dengan $\mathrm{pH} 3 ; 4$; 5; dan 6

8. Penentuan Pengaruh $\mathrm{pH}$ dan Penambahan Ion $\mathrm{Cr}(\mathrm{VI})$ terhadap Serapan Logam Cu(II) oleh Serbuk Kulit Kacang Tanah

Menimbang 0,5 gram adsorben serbuk kulit kacang tanah dengan neraca analitik, memasukkan adsorben ke dalam labu Erlenmeyer yang berisi campuran larutan logam $\mathrm{Cu}(\mathrm{II})$ dan $\mathrm{Cr}(\mathrm{VI})$ dengan $\mathrm{pH}$ 2, lalu menutup rapat, mengaduk dengan shaker selama 60 menit dengan kecepatan $125 \mathrm{rpm}$, menyaring masing-masing campuran yang telah diaduk menggunakan kertas saring Whatmann 42 dan mengukur absorbansi filtrat tersebut dengan menggunakan Spektrofotometri Serapan Atom (SSA), melakukan hal yang 
sama seperti di atas untuk campuran larutan $\mathrm{Cu}(\mathrm{II})$ dan $\mathrm{Cr}(\mathrm{VI}) 50$ ppm dengan $\mathrm{pH} 3 ; 4 ; 5$; dan 6 .

\section{Teknik Analisis Data}

Data yang diperoleh dianalisis secara kuantitatif yaitu menentukan besarnya konsentrasi ion logam $\mathrm{Cu}(\mathrm{II})$ yang terserap oleh serbuk kulit kacang tanah untuk mengetahui pengaruh $\mathrm{pH}$ dan penambahan ion $\mathrm{Cr}(\mathrm{VI})$ terhadap serapan $\mathrm{Cu}(\mathrm{II})$. Pengukuran besarnya konsentrasi $\mathrm{Cu}$ (II) yang terserap dilakukan setelah larutan sampel dikontakkan dengan adsorben serbuk kulit kacang tanah dengan waktu kontak selama 60 menit. Analisis konsentrasi $\mathrm{Cu}$ (II) terhadap $\mathrm{pH}$ dan penambahan ion Cr(VI) ini menggunakan instrumen Spektrofotometri Serapan Atom (SSA).

Pada penentuan pengaruh $\mathrm{pH}$ terhadap serapan $\mathrm{Cu}$ (II) digunakan variasi $\mathrm{pH} 2$; $3 ; 4 ; 5 ; 6$ sebagai variabel bebas. Sedangkan variabel terikatnya adalah konsentrasi $\mathrm{Cu}(\mathrm{II})$ yang terjerap oleh adsorben serbuk kulit kacang tanah. Untuk mengetahui pengaruh $\mathrm{pH}$ terhadap daya adsorpsi $\mathrm{Cu}$ (II) oleh adsorben serbuk kulit kacang tanah maka dibuat grafik hubungan antara $\mathrm{pH}$ larutan dengan \% $\mathrm{Cu}(\mathrm{II})$ yang terjerap.

Pada penentuan pengaruh penambahan ion $\mathrm{Cr}(\mathrm{VI})$ terhadap serapan $\mathrm{Cu}(\mathrm{II})$ dilakukan pencampuran logam $\mathrm{Cu}(\mathrm{II})$ dan $\mathrm{Cr}(\mathrm{VI})$ sehingga konsentrasi masingmasing larutan logam pada campuran menjadi 50 ppm pada variasi $\mathrm{pH} 2 ; 3 ; 4 ; 5$; 6 sebagai variabel bebas. Sedangkan variabel terikatnya adalah konsentrasi $\mathrm{Cu}$ (II) yang terjerap oleh adsorben serbuk kulit kacang tanah. Untuk mengetahui pengaruh penambahan ion $\mathrm{Cr}(\mathrm{VI})$ terhadap daya adsorpsi $\mathrm{Cu}(\mathrm{II})$ oleh adsorben serbuk kulit kacang tanah maka dibuat grafik hubungan antara $\mathrm{pH}$ larutan dengan $\% \mathrm{Cu}(\mathrm{II})$ yang terjerap baik dengan penambahan ion $\mathrm{Cr}(\mathrm{VI})$ ataupun tidak.

Pada analisis selanjutnya adalah menentukan isoterm adsorpsi yang menunjukkan pola adsorpsi yang terjadi dengan menggunakan serbuk kulit kacang tanah.Karakterisasi adsorben serbuk kulit kacang tanah dilakukan dengan menggunakan instrumen FTIR untuk mengetahui struktur serbuk kulit kacang tanah.

\section{HASIL DAN PEMBAHASAN}

Penelitian ini bertujuan untuk mengetahui apakah serbuk kulit kacang tanah dapat dimanfaatkan sebagai adsorben ion logam $\mathrm{Cu}(\mathrm{II})$ sehingga dapat mengurangi pencemaran ion logam $\mathrm{Cu}$ (II) dalam limbah cair dan limbah kulit kacang tanah pada lingkungan. Selain itu juga untuk mengetahui pengaruh penambahan ion $\mathrm{Cr}(\mathrm{VI})$ terhadap serapan $\mathrm{Cu}(\mathrm{II})$ pada berbagai $\mathrm{pH}$ oleh serbuk kulit kacang tanah.

Kulit kacang tanah merupakan hasil samping dari pengolahan hasil pertanian yang mengandung selulosa $(63,5 \%)$ dan lignin $(13,2 \%)$. Selulosa mempunyai potensi yang cukup besar untuk dijadikan penjerap, karena gugus-OH yang terikat dapat berinteraksi dengan komponen adsorbat, sehingga dapat dijadikan sebagai adsorben logam berat yang bermuatan positif. Gugus fungsi yang terdapat pada kulit kacang tanah diketahui dengan dilakukan analisis menggunakan instrumen FTIR dan diperoleh spektra sebagai berikut: 


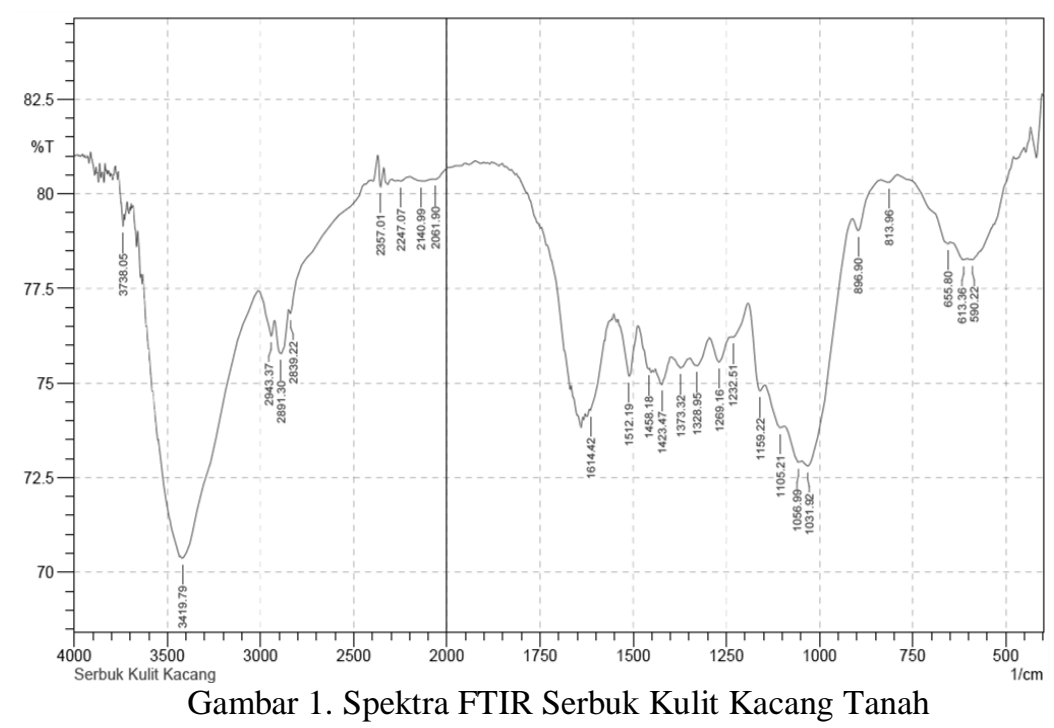

Berdasarkan spektra FTIR yang telah diperoleh, diketahui bahwa di dalam serbuk kulit kacang tanah terdapat gugus $-\mathrm{OH}$ (gugus hidroksi) yang dibuktikan dengan adanya puncak/serapan khas yang tajam dan melebar pada angka gelombang 3419,79 $\mathrm{cm}^{-1}$, merupakan vibrasi regangan (stretching) dari gugus $\mathrm{OH}$ yang terdapat pada struktur selulosa serbuk kulit kacang tanah dengan intensitas gugus $-\mathrm{OH}$ pada serbuk kulit kacang tanah 78,262. Gugus $\mathrm{C}=\mathrm{O}$ (karbonil) ditunjukkan adanya puncak/serapan pada angka gelombang 1614,42 $\mathrm{cm}^{-1}$, merupakan vibrasi regangan (stretching) darialdehid dan keton. Gugus -OH disertai dengan gugus karbonil menunjukkan pada adsorben serbuk kulit kacang tanah mengandung gugus asam karboksilat. Adanya gugus $\mathrm{C}_{\mathrm{sp} 3}-\mathrm{H}$ ditunjukkan serapan pada $2891,30 \mathrm{~cm}^{-1}$ yang merupakan gugus metil $\left(-\mathrm{CH}_{3}\right)$ yakni pada serapan 1328,95 $\mathrm{cm}^{-1}$ dan gugus metilen $\left(-\mathrm{CH}_{2-}\right)$ pada serapan $1423,47 \mathrm{~cm}^{-1}$. Puncak yang terdapat pada angka gelombang $1056,99 \mathrm{~cm}^{-1}$ dan $1031,92 \mathrm{~cm}^{-1}$ menunjukkan gugus C-H dan C-O (Sastrohamidjojo, 2011). Hal ini sesuai dengan penelitian yang telah dilakukan oleh Qaiser, Saleemi, \& Umar(2009), yang menyebutkan bahwa pada kulit kacang tanah mengandung gugus $-\mathrm{OH}$, karbonil, $\mathrm{C}-\mathrm{H}$, dan $\mathrm{C}-\mathrm{O}$ yang merupakan gugus penting dalam proses adsorpsi.

\section{Adsorpsi Ion Logam Cu(II)oleh Adsorben Serbuk Kulit Kacang Tanah}

Adsorpsi merupakan proses penjerapan pada permukaan adsorben, dimana adsorben adalah zat yang mengadsorpsi sedangkan zat yang diadsorpsi disebut adsorbat. Dalam penelitian ini yang berperan sebagai adsorben adalah serbuk kulit kacang tanah sedangkan adsorbatnya adalah ion logam $\mathrm{Cu}(\mathrm{II})$ dalam larutan. Adsorpsi terjadi karena adanya gaya tarik kearah dalam dari molekul-molekul pada permukaan zat padat dan zat cair (gaya adsorpsi) dimana zat yang diserap hanya pada permukaan.

Di dalam serbuk kulit kacang tanah terdapat gugus fungsi hidroksi(-OH) sehingga antara serbuk kulit kacang tanah dengan ion logam $\mathrm{Cu}$ (II) dapat terjadi gaya tarik ke arah permukaan serbuk kulit kacang tanah yang menyebabkan ion logam dapat terjerap.

Keputusan Menteri Pertanian No. 511 Tahun 2006 Tentang Jenis Komoditi 
Tanaman Binaan Direktorat Jenderal Perkebunan, komposisi kulit kacang tanah terdiri atas 9,5\% air, 3,6\% abu, 8,4\%, protein, 63,5\% selulosa, 13,2\% lignin, dan $1,8 \%$ lemak. Selulosa dan lignin ini berperan dalam mengokohkan tanaman. Selulosa memiliki gugus $-\mathrm{OH}$ yang berperan dalam proses adsorpsi secara kimia. Berikut adalah struktur dari selulosa. Adanya gugus $-\mathrm{OH}$ yang terdapat di dalam selulosa memungkinkan adanya penyerapan ion logam karena terjadi pertukaran ion. Berikut mekanisme yang mungkin terjadi:

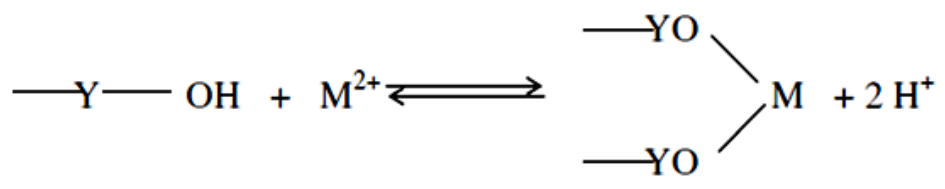

Gambar 2. Mekanisme pertukaran kation dalam selulosa (Yantri, 1998)

$\mathrm{M}^{2+}$ adalah ion logam, -OH adalah gugus hidroksil, dan $\mathrm{Y}$ adalah matriks tempat gugus -OH terikat. Interaksi antara gugus -OH dengan ion logam memungkinkan melalui mekanisme pembentukan kompleks koordinasi karena atom oksigen (O) pada gugus - $\mathrm{OH}$ mempunyai pasangan elektron bebas, sedangkan ion logam mempunyai orbital d kosong. Pasangan elektron bebas tersebut akan menempati orbital kosong yang dimiliki oleh ion logam, sehingga terbentuk suatu senyawa atau ion kompleks.

1. Penentuan Pengaruh pH Terhadap Serapan Cu(II) Pada Adsorben Serbuk Kulit Kacang Tanah

Penentuan pengaruh $\mathrm{pH}$ terhadap serapan $\mathrm{Cu}(\mathrm{II})$ dilakukan pada $\mathrm{pH} 2$; 3; 4; 5; dan 6. Pemilihan rentang $\mathrm{pH}$ tersebut berdasarkan pada penelitian yang telah dilakukan oleh (Qaiser et al.,2009) bahwa jika menggunakan pH lebih dari 6, logam akan mengendap. Berkaitan dengan hal tersebut maka pada penelitian ini tidak digunakan $\mathrm{pH}$ di atas 6.

Salah satu faktor yang mempengaruhi proses penyerapan ion logam berat oleh adsorben adalah derajat keasaman $(\mathrm{pH})$, yang dapat menyebabkan perubahan sifat permukaan adsorben, sifat molekul adsorbat, perubahan komposisi larutan, dan mempengaruhi spesies logam yang ada dalam larutan sehingga akan mempengaruhi terjadinya interaksi ion logam dengan adsorben.Pada $\mathrm{pH}$ tinggi (kondisi basa) cenderung akan terjadi adsorpsi kation pada adsorben, sedangkan pada $\mathrm{pH}$ rendah (kondisi asam) cenderung terjadi adsorpsi anion.

Pada penelitian ini mekanisme adsorpsi melalui pertukaran ion :

$$
\mathrm{S}-\mathrm{H}_{\alpha}+\mathrm{M}^{2+} \leftrightarrow \mathrm{S}-\mathrm{M}+\alpha \mathrm{H}^{+}
$$

Dimana $\mathrm{S}-\mathrm{H}$ mewakili situs adsorpsi permukaan adsorben, $\mathrm{M}^{2+}$ merupakan konsentrasi kesetimbangan ion logam, S-M adalah logam yang teradsorpsi pada serbuk biomassa, sedangkan $\alpha$ adalah koefisien protonik. Pada proses ini terjadi kompetisi antara ion $\mathrm{H}^{+}$dan ion logam terhadap situs pertukaran kation. Pada $\mathrm{pH}$ tinggi (konsentrasi ion $\mathrm{H}^{+}$makin kecil) kompetisi antara ion $\mathrm{H}^{+}$dengan ion logam menjadi berkurang sehingga jumlah logam yang teradsorpsi makin besar dibanding dengan $\mathrm{pH}$ rendah. Dari kedua model di atas menunjukkan bahwa adsorpsi logam pada permukaan adsorben 
tergantung pada $\mathrm{pH}$ sehingga $\mathrm{pH}$ merupakan suatu variabel yang menentukan proses adsorpsi.

Berdasarkan mekanisme tersebutpengaruh $\mathrm{pH}$ terhadap adsorpsi $\mathrm{Cu}(\mathrm{II})$ dapat dijelaskan dengan metode pertukaran ion berikut:

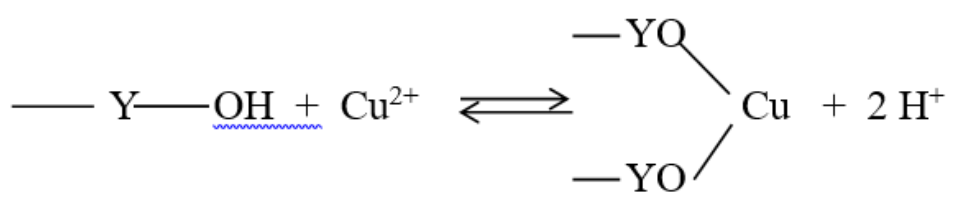

Gambar 3. Mekanisme Pertukaran Ion Logam Cu dalam Selulosa

Berikut adalah data hasil adsorpsi ion logam $\mathrm{Cu}(\mathrm{II})$ dengan menggunakan serbuk kulit kacang tanah pada penentuan pengaruh $\mathrm{pH}$ terhadap serapan $\mathrm{Cu}(\mathrm{II})$.

Tabel 1. Data pH terhadap Absorbansi Larutan Ion Logam $\mathrm{Cu}(\mathrm{II})$

\begin{tabular}{ccccc}
\hline pH & $\begin{array}{c}\text { Konsentrasi Awal } \\
\mathrm{Cu}(\mathrm{II})(\mathrm{ppm})\end{array}$ & $\begin{array}{c}\text { Konsentrasi Akhir } \\
\mathrm{Cu}(\mathrm{II})(\mathrm{ppm})\end{array}$ & $\begin{array}{c}\text { Konsentrasi Cu(II) } \\
\text { Terserap (ppm) }\end{array}$ & $\begin{array}{c}\text { Kadar Cu(II) } \\
\text { Terserap (\%) }\end{array}$ \\
\hline 2 & 48,647 & 5,181 & 43,466 & 89,349 \\
3 & 49,678 & 3,266 & 46,412 & 93,425 \\
4 & 50,245 & 2,926 & 47,319 & 94,176 \\
5 & 51,186 & 3,039 & 48,147 & 94,062 \\
6 & 53,815 & 2,779 & 51,036 & 94,836 \\
\hline
\end{tabular}

Dari data di atas dapat dibuat grafik hubungan antara $\mathrm{pH}$ terhadap persentase kadar $\mathrm{Cu}(\mathrm{II})$ yang terserap sebagai berikut:

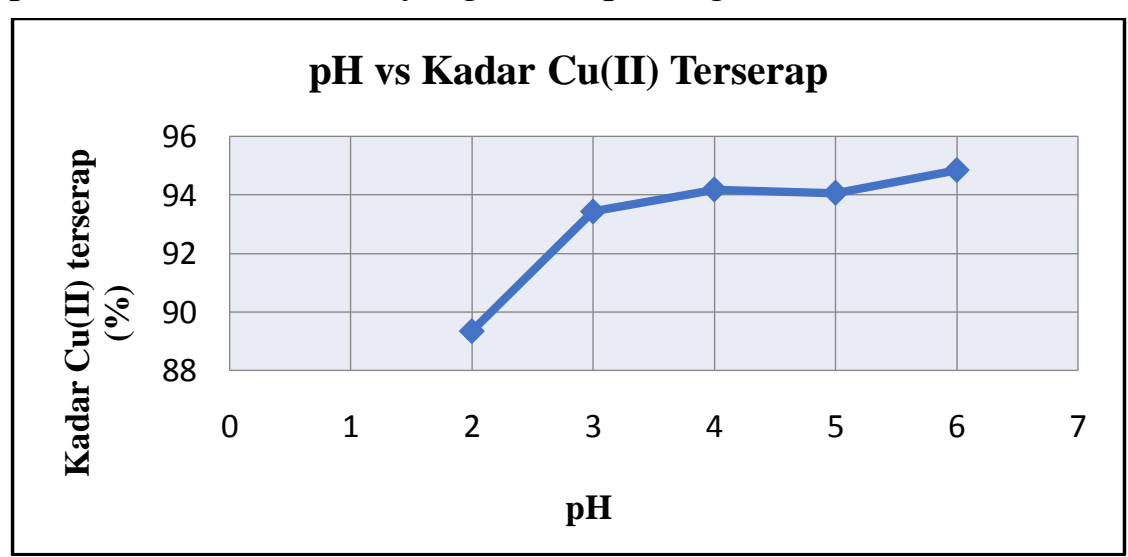

Gambar 4. Grafik Hubungan antara pH terhadap Persentase Kadar Cu(II) yang Terserap

Berdasarkan grafik hasil analisa, semakin besar $\mathrm{pH}$ adsorpsi terhadap logam semakin besar. Hal ini disebabkan karena pada $\mathrm{pH}$ rendah kandungan ion $\mathrm{H}^{+}$dalam larutan cukup tinggi. Ion $\mathrm{H}^{+}$dapat berkompetisi dengan ion $\mathrm{Cu}^{2+}$ dalam berikatan dengan gugus yang terkandung pada serbuk kulit kacang tanah yaitu $-\mathrm{OH}$, sehingga pada $\mathrm{pH}$ rendah daya serap serbuk kulit kacang tanah terhadap logam $\mathrm{Cu}$ (II)kecil. Pada $\mathrm{pH} 2$, adsorpsi $\mathrm{Cu}(\mathrm{II})$ oleh serbuk kulit kacang tanah menghasilkan persentase $\mathrm{Cu}$ (II) teradsorpsi paling kecil yaitu 
sebesar $89,349 \%$. Semakin bertambahnya $\mathrm{pH}$, persentase $\mathrm{Cu}$ (II) teradsorpsi semakin bertambah, namun pada $\mathrm{pH} 5$ terjadi sedikit penurunan yaitu dari 94,176\% pada $\mathrm{pH} 4$ menjadi 94,062\% lalu mengalami kenaikan kembali pada pH 6 menjadi 94,836\%.

2. Penentuan Pengaruh pH Dan Penambahan Ion $\mathrm{Cr}$ (VI) Terhadap Serapan $\mathrm{Cu}$ (II) Pada Adsorben Serbuk Kulit Kacang Tanah

Penentuan pengaruh $\mathrm{pH}$ dan penambahan ion $\mathrm{Cr}(\mathrm{VI})$ terhadap serapan $\mathrm{Cu}$ (II) dilakukan pada $\mathrm{pH}$ yang sama yaitu 2, 3, 4, 5 dan 6. Perbedaan dengan percobaan sebelumnya yaitu pada penambahan larutan logam $\mathrm{Cr}(\mathrm{VI})$ pada masing-masing larutan logam $\mathrm{Cu}(\mathrm{II})$ pada $\mathrm{pH}$ tersebut. Data hasil percobaan dapat dilihat pada Tabel 2.

Tabel 2. Data $\mathrm{pH}$ terhadap Absorbansi Larutan Ion Logam $\mathrm{Cu}(\mathrm{II})$ dengan Penambahan Ion Cr(VI)

\begin{tabular}{ccccc}
\hline $\mathrm{pH}$ & $\begin{array}{c}\text { Konsentrasi Awal } \\
\mathrm{Cu}(\mathrm{II})(\mathrm{ppm})\end{array}$ & $\begin{array}{c}\text { Konsentrasi Akhir } \\
\mathrm{Cu}(\mathrm{II})(\mathrm{ppm})\end{array}$ & $\begin{array}{c}\text { Konsentrasi } \\
\mathrm{Cu}(\mathrm{II}) \text { Terserap } \\
(\mathrm{ppm})\end{array}$ & $\begin{array}{c}\text { Kadar } \\
\mathrm{Cu}(\mathrm{II}) \\
\text { Terserap } \\
(\%)\end{array}$ \\
\hline 2 & 51,367 & 6,168 & 45,199 & 7,992 \\
3 & 50,562 & 4,252 & 46,310 & 1,590 \\
4 & 51,707 & 1,634 & 50,073 & 6,839 \\
5 & 53,260 & 0,433 & 52,827 & 9,187 \\
6 & 51,786 & 0,070 & 51,716 & 9,864 \\
\hline
\end{tabular}

Dari data di atas dapat dibuat grafik hubungan antara $\mathrm{pH}$ terhadap persentase kadar $\mathrm{Cu}(\mathrm{II})$ yang terserap sebagai berikut:

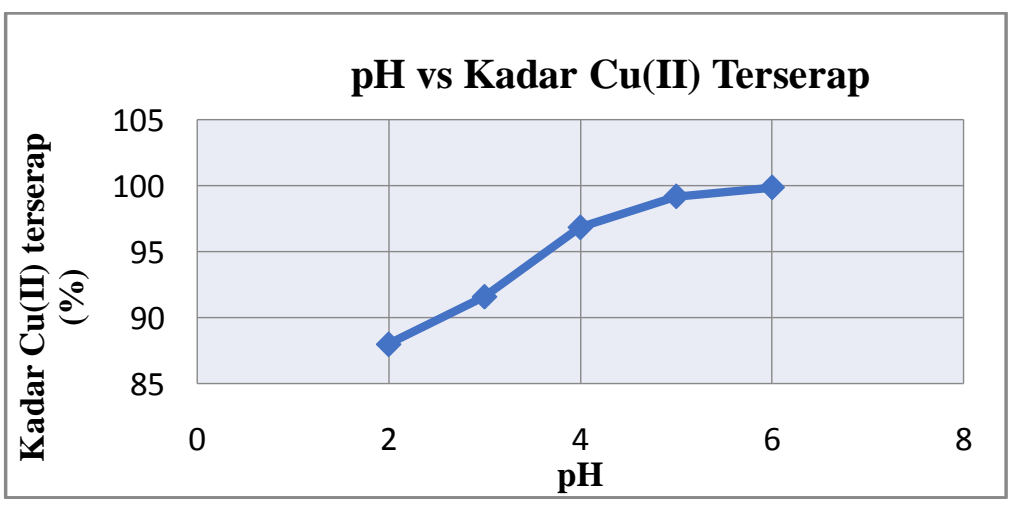

Gambar 5. Grafik Hubungan antara pH terhadap Persentase Kadar Cu(II) yang Terserap dengan Penambahan Ion Cr(VI)

Perbandingan kemampuan adsorpsi serbuk kulit kacang tanah terhadap $\mathrm{Cu}(\mathrm{II})$ dengan dan tanpa penambahan ion $\mathrm{Cr}(\mathrm{VI})$ dapat dilihat pada Gambar 5 berikut: 


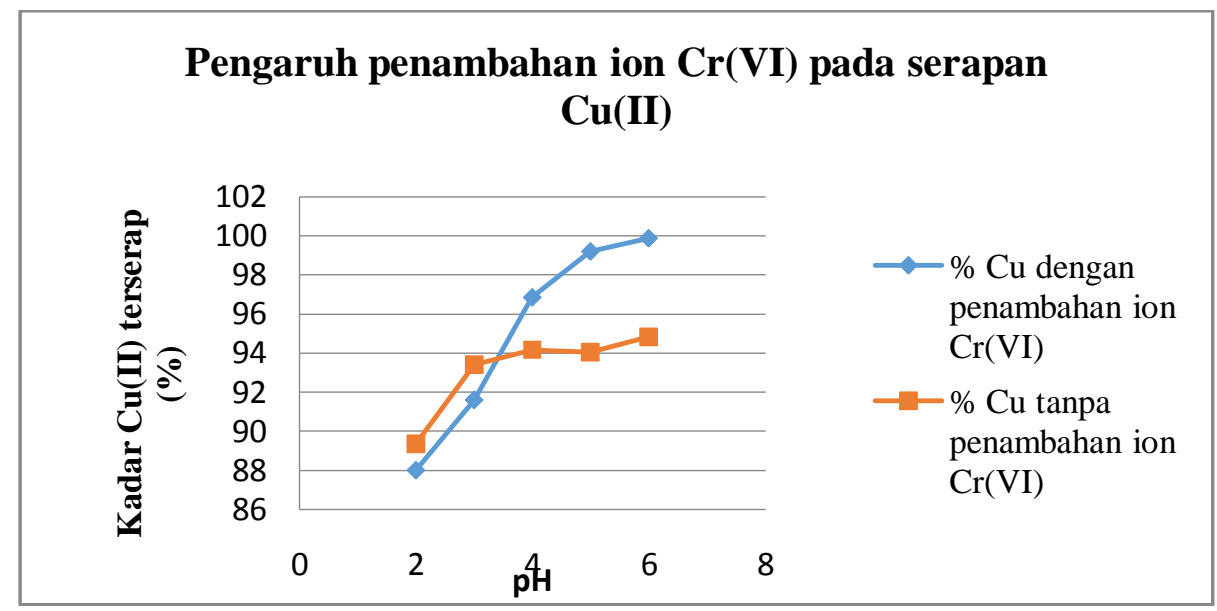

Gambar 6. Grafik Pengaruh Penambahan Ion Logam Cr(VI) pada Serapan Cu(II)

Berdasarkan grafik perbandingan tersebut, menunjukkan bahwa semakin bertambah $\mathrm{pH}$ jumlah $\mathrm{Cu}(\mathrm{II})$ yang teradsorpsi semakin banyak. Pengaruh penambahan ion $\mathrm{Cr}(\mathrm{VI})$ secara signifikan hanya ditunjukkan pada $\mathrm{pH}$ diatas 3,5 hingga 6. Pada rentang pH 2 sampai 3,5 keberadaan $\mathrm{Cr}(\mathrm{VI})$ memperkecil daya serap serbuk kulit kacang tanah terhadap $\mathrm{Cu}$ (II). Namun pada $\mathrm{pH} 3,5$ sampai 6 jumlah $\mathrm{Cu}(\mathrm{II})$ yang teradsorpsi menunjukkan kecenderungan meningkat, disebabkan karena adanya interaksi antara anion $\mathrm{Cr}(\mathrm{VI})$, kation $\mathrm{Cu}(\mathrm{II})$ dan gugus fungsional serbuk kulit kacang tanah.

Mekanisme yang mungkin dapat menjelaskan efek $\mathrm{Cr}(\mathrm{VI})$ pada adsorpsi $\mathrm{Cu}(\mathrm{II})$ adalah bahwa pada $\mathrm{pH}$ rendah konsentrasi $\mathrm{H}^{+}$tinggi sehingga gugus fungsional serbuk kulit kacang tanah yaitu - $\mathrm{OH}$ lebih cenderung untuk mengikat ion $\mathrm{Cr}(\mathrm{VI})$ yang bermuatan negatif daripada ion $\mathrm{Cu}(\mathrm{II})$ yang bermuatan positif. Hal ini menyebabkan adanya kompetisi serapan antara ion $\mathrm{Cu}$ (II) dan ion $\mathrm{Cr}(\mathrm{VI})$, sehingga daya serap serbuk kulit kacang tanah terhadap ion $\mathrm{Cu}(\mathrm{II})$ menjadi berkurang. Sedangkan pada $\mathrm{pH}$ tinggi konsentrasi $\mathrm{H}^{+}$ berkurang. Penambahan ion $\mathrm{Cr}(\mathrm{VI})$ pada larutan $\mathrm{Cu}$ (II) meningkatkan muatan negatif pada permukaan adsorben, sehingga dapat meningkatkan daya serap adsorben serbuk kulit kacang tanah terhadap $\mathrm{Cu}$ (II) yang bermuatan positif.

\section{Penentuan Kapasitas Adsorpsi}

Kapasitas adsorpsi dapat diartikan bahwa tiap gram adsorben serbuk kulit kacang tanah dapat mengadsorpsi $\mathrm{x} \mathrm{mg}$ ion $\mathrm{Cu}(\mathrm{II})$.Pada penelitian ini, konsentrasi ion logam $\mathrm{Cu}(\mathrm{II})$ yang digunakan adalah $50 \mathrm{ppm}$. Maka pada saat pembacaan adsorbansi dengan instrumen Spektrofotometri Serapan Atom (SSA), larutan $\mathrm{Cu}(\mathrm{II})$ perlu diencerkan terlebih dahulu hingga 10 kali pengenceran agar konsentrasi yang terbaca tidak melewati kurva kalibrasi (agar tidak terjadi penyimpangan hukum Lambert-Beer). Variasi $\mathrm{pH}$ yang digunakan $2 ; 3 ; 4 ; 5 ; 6$ dan penambahan ion $\mathrm{Cr}(\mathrm{VI})$. Kapasitas adsorpsi dengan $\mathrm{pH}$ ditunjukkan sebagai berikut: 
Tabel 3. Data Kapasitas Adsorpsi

\begin{tabular}{cc}
\multicolumn{2}{c}{ Kapasitas adsorpsi tanpa $\mathrm{Cr}(\mathrm{VI})$} \\
\hline $\mathrm{Ph}$ & $\begin{array}{c}\text { Massa terserap, } \\
\text { Qe }(\mathrm{mg} / \mathrm{g})\end{array}$ \\
\hline 2 & 2,1733 \\
3 & 2,3206 \\
4 & 2,36595 \\
5 & 2,40735 \\
6 & 2,5518 \\
\hline
\end{tabular}

\begin{tabular}{cc}
\hline \multicolumn{2}{c}{ Kapasitas adsorpsi dengan Cr(VI) } \\
\hline $\mathrm{pH}$ & $\begin{array}{c}\text { Massa terserap, } \\
\text { Qe (mg/g) }\end{array}$ \\
\hline 2 & 2,25995 \\
3 & 2,3155 \\
4 & 2,50365 \\
5 & 2,64135 \\
6 & 2,5858 \\
\hline
\end{tabular}

Dari data di atas dapat diperoleh grafik hubungan kapasitas adsorpsi dengan $\mathrm{pH}$ sebagai berikut:

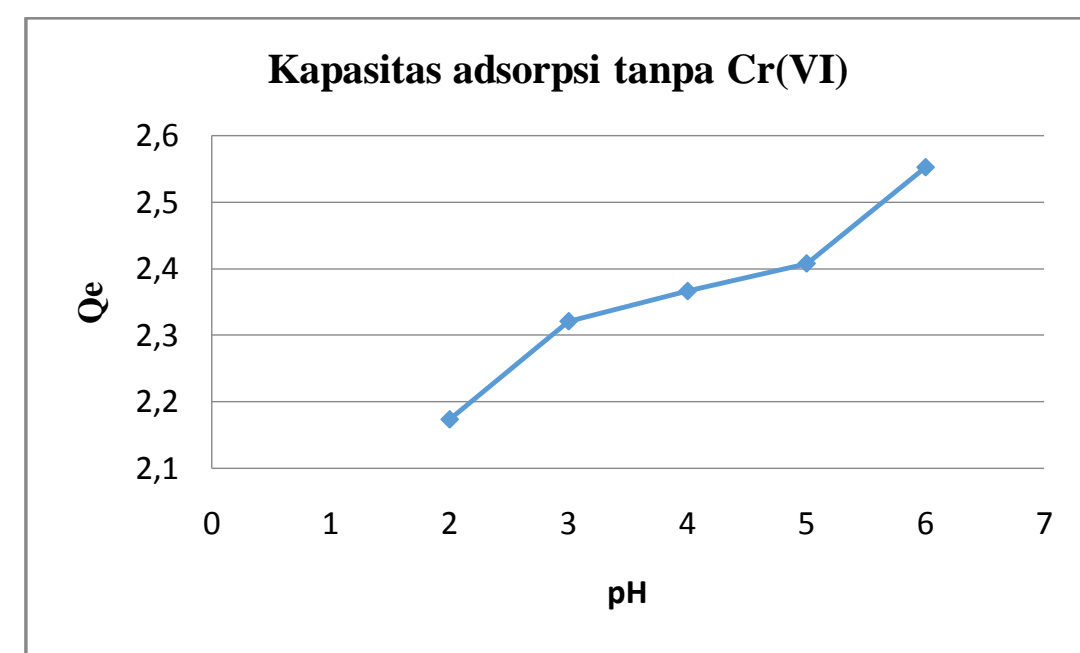

Gambar 7. Grafik Hubungan antara Kapasitas Adsorpsi dengan pH Tanpa Penambahan Ion Cr(VI)

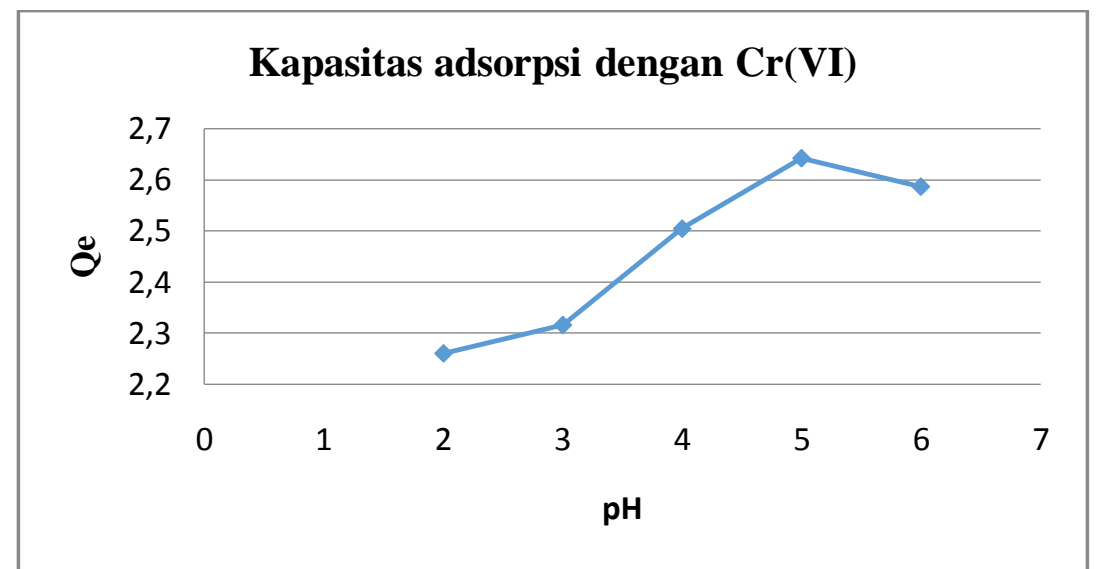

Gambar 8. Grafik Hubungan antara Kapasitas Adsorpsi dengan pH dengan Penambahan Ion Cr(VI)

Hasil analisa menunjukkan untuk ion logam $\mathrm{Cu}(\mathrm{II})$ dengan variasi $\mathrm{pH}$ diperoleh kapasitas adsorpsi terbesar pada $\mathrm{pH} 6$ yakni sebesar 2,5518 mg/g dan adsorpsi terkecilnya pada $\mathrm{pH} 2$ yaitu $2,1733 \mathrm{mg} / \mathrm{g}$, maka semakin besar 
pH kapasitas adsorpsi serbuk kulit kacang tanah terhadap $\mathrm{Cu}$ (II) semakin besar pada rentang $\mathrm{pH}$ 2- 6. Sedangkan pada percobaan kedua dengan variasi $\mathrm{pH}$ dan penambahan ion $\mathrm{Cr}(\mathrm{VI})$ diperoleh kapasitas adsorpsi terbesar pada $\mathrm{pH}$ 5 yakni sebesar 2,64135 mg/g dan adsorpsi terkecilnya pada $\mathrm{pH} 2$ yaitu 2,25995 mg/g. Besarnya kapasitas adsorpsi meningkat seiring dengan meningkatnya $\mathrm{pH}$, namun setelah mencapai $\mathrm{pH} 5$ kapasitas adsorpsi menurun.

Pada data tersebut menyatakan bahwa semakin besar $\mathrm{pH}$ maka banyaknya ion logam yang terserap juga semakin banyak. Penambahan ion logam $\mathrm{Cr}(\mathrm{VI})$ juga berpengaruh pada kemampuan adsorpsi serbuk kulit kacang tanah terhadap ion logam $\mathrm{Cu}(\mathrm{II})$. Pada $\mathrm{pH}$ tinggi, kapasitas adsorpsi $\mathrm{Cu}$ (II) dengan penambahan ion $\mathrm{Cr}(\mathrm{VI})$ lebih besar daripada tanpa $\mathrm{Cr}(\mathrm{VI})$. Hal ini disebabkan karena $\mathrm{Cr}(\mathrm{VI})$ dapat meningkatkan muatan negatif pada sisi aktif permukaan adsorben serbuk kulit kacang tanah.

\section{Analisis Isoterm Adsorpsi Ion Logam Cu(II) Oleh Adsorben Serbuk Kulit Kacang Tanah}

Isoterm adsorpsi adalah hubungan antara jumlah zat yang diadsorpsi dan tekanan kesetimbangan atau konsentrasi kesetimbangan pada temperatur tertentu (Sukardjo, 2002:191). Dalam penelitian ini jenis isoterm adsorpsi yang akan dianalisis ada 2, yaitu isoterm Langmuir dan isoterm Freundlich. Penentuan pola isoterm menggunakan variasi $\mathrm{pH}$ tanpa penambahan ion $\mathrm{Cr}(\mathrm{VI})$ dan variasi $\mathrm{pH}$ dengan penambahan ion $\mathrm{Cr}(\mathrm{VI})$.

Isoterm adsorpsi Langmuir menunjukkan bahwa proses adsorpsi yang terjadi adalah jenis adsorpsi kimia sedangkan isoterm adsorpsi Freundlich menunjukkan bahwa adsorpsi terjadi secara fisika. Dari kedua persamaan tersebut kemudian dibandingkan harga $\mathrm{R}^{2}$ (koefisien korelasi) masing-masing. Persamaan dengan harga $\mathrm{R}^{2}$ yang lebih besar maka persamaan itulah yang berlaku pada sistem adsorpsi yang dilakukan(Sivaprakash, Rajamohan, \& Sadhik, 2010)

Data dan perhitungan untuk variasi $\mathrm{pH}$ ion $\mathrm{Cu}(\mathrm{II})$ tanpa penambahan ion $\mathrm{Cr}(\mathrm{VI})$ memberikan harga $\mathrm{R}^{2}$ isoterm adsorpsi Langmuir lebih besar $\left(\mathrm{R}^{2}=0,853\right)$ daripada isoterm adsorpsi Freundlich $\left(\mathrm{R}^{2}=0,797\right.$. Hal ini menunjukkan bahwa proses adsorpsi untuk variasi $\mathrm{pH}$ pada ion logam $\mathrm{Cu}^{2+}$ tanpa penambahan ion $\mathrm{Cr}(\mathrm{VI})$ terjadi secara kimia. Sedangkan untuk variasi $\mathrm{pH}$ ion $\mathrm{Cu}(\mathrm{II})$ dengan penambahan ion $\mathrm{Cr}(\mathrm{VI})$, harga $\mathrm{R}^{2}$ isoterm adsorpsi Freundlich lebih besar $\left(\mathrm{R}^{2}=0,720\right)$ dibandingkan dengan isotermLangmuir sebesar $\left(\mathrm{R}^{2}=0,282\right)$, yang menunjukkan bahwa proses adsorpsi terjadi secara fisika.

Proses adsorpsi yang terjadi untuk variasi $\mathrm{pH}$ pada ion logam $\mathrm{Cu}^{2+}$ tanpa penambahan ion $\mathrm{Cr}(\mathrm{VI})$ merupakan proses adsorpsi secara kimia dimana ion logam $\mathrm{Cu}^{2+}$ berinteraksi dengan gugus $-\mathrm{OH}$ yang terdapat dalam selulosa dari serbuk kulit kacang tanah. Dalam proses tersebut $\mathrm{Cu}^{2+}$ menstubtitusi atom $\mathrm{H}^{+}$pada gugus $-\mathrm{OH}$, berikut mekanisme reaksi yang mungkin terjadi: 


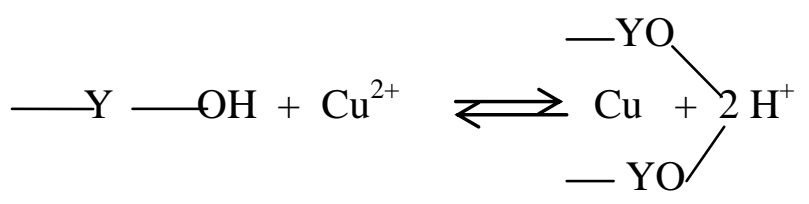

Gambar 9. Mekanisme reaksi adsorpsi ion logam $\mathrm{Cu}^{2+}$

Mekanisme reaksi tersebut maka dapat diketahui bahwa terjadi reaksi antara ion logam $\mathrm{Cu}^{2+}$ dengan gugus $-\mathrm{OH}$ pada serbuk kulit kacang tanah sehingga ion logam $\mathrm{Cu}^{2+}$ dapat berinteraksi dengan serbuk kulit kacang tanah membentuk senyawa. Interaksi inilah yang menyebabkan ion logam $\mathrm{Cu}^{2+}$ dalam larutan dapat mengalami penurunan (terjadi proses adsorpsi secara kimia).

Proses adsorpsi yang terjadi untuk variasi $\mathrm{pH}$ pada ion logam $\mathrm{Cu}(\mathrm{II})$ dengan penambahan ion $\mathrm{Cr}(\mathrm{VI})$ merupakan proses adsorpsi secara fisika. Adsorpsi fisika merupakan adsorpsi yang disebabkan oleh gaya van der Walls yang ada pada permukaan adsorben. Jadi dapat dijelaskan bahwa terserapnya ion logam $\mathrm{Cu}^{2+}$ dalam serbuk kulit kacang tanah dengan penambahan ion $\mathrm{Cr}(\mathrm{VI})$ karena adanya gaya Van Der Walls (gaya elektrostatik) yaitu gaya tarik-menarik antara molekul dalam senyawa. Gaya ini timbul akibat adanya dipol-dipol yang muatannya berlawanan yaitu gugus $-\mathrm{OH}$ yang bermuatan negatif dengan ion logam $\mathrm{Cu}^{2+}$. Penambahan ion $\mathrm{Cr}(\mathrm{VI})$ mengakibatkan bertambahnya muatan negatif pada sisi aktif serbuk kulit kacang tanah, sehingga menyebabkan adanya tarikan antara ion logam $\mathrm{Cu}^{2+}$ dengan molekul adsorben yaitu $-\mathrm{OH}$.

Proses adsorpsi pada kedua perlakuan mengikuti pola/ persamaan isoterm adsorpsi yang berbeda. Ketika ion $\mathrm{Cu}(\mathrm{II})$ tidak dipengaruhi keberadaan $\mathrm{Cr}(\mathrm{VI})$ terserap secara kimia, dalam proses tersebut $\mathrm{Cu}(\mathrm{II})$ menstubtitusi atom $\mathrm{H}^{+}$pada gugus $-\mathrm{OH}$. Sedangkan saat ion $\mathrm{Cu}$ (II) dipengaruhi keberadaan $\mathrm{Cr}(\mathrm{VI})$ terserap secara fisika. Hal ini disebabkan karena gaya van der Walls yang timbul akibat adanya muatan yang berlawanan, terlebih dengan penambahan ion $\mathrm{Cr}(\mathrm{VI})$ dapat menambah muatan negatif pada sisi aktif adsorben serbuk kulit kacang tanah, sehingga akan menambah daya tarik menarik antara molekul dalam senyawa.

\section{KESIMPULAN DAN SARAN \\ Kesimpulan}

Dari hasil penelitian ini dapat diambil kesimpulan sebagai berikut: 1)serbuk kulit kacang tanah dapat digunakan sebagai adsorben ion logam $\mathrm{Cu}(\mathrm{II}), 2$ )semakin besar $\mathrm{pH}$ daya serap serbuk kulit kacang terhadap logam $\mathrm{Cu}(\mathrm{II})$ semakin meningkat, daya serap terbesar pada $\mathrm{pH} 6$ yaitu sebesar 94,836\%, 3)pada $\mathrm{pH}$ diatas 3,5 penambahan ion logam $\mathrm{Cr}(\mathrm{VI})$ memperbesar daya serap serbuk kulit kacang tanah terhadap logam $\mathrm{Cu}(\mathrm{II})$, sedangkan pada $\mathrm{pH}$ dibawah 3,5 cenderung memperkecil daya serap adsorben terhadap $\mathrm{Cu}(\mathrm{II})$, daya adsorpsi terbesar pada $\mathrm{pH}$ 6 yaitu sebesar 99,864\%, 4)jenis adsorbsi oleh serbuk kulit kacang tanah yang terjadi untuk variasi $\mathrm{pH}$ tanpa penambahan ion logam $\mathrm{Cr}(\mathrm{VI})$ adalah adsorbsi 
kimia, sedangkan jenis adsorbsi untuk variasi $\mathrm{pH}$ dengan penambahan ion logam $\mathrm{Cr}(\mathrm{VI})$ adalah adsorpsi fisika.

\section{Saran}

Saran sebagai kelanjutan dari penelitian ini adalah sebagai berikut: 1)perlu dilakukan penelitian lanjutan untuk memperoleh adsorben yang lebih efektif untuk mengadsorbsi ion logam $\mathrm{Cu}$ (II) atau logam lain yang berbahaya, 2)mengaplikasikan adsorben serbuk kulit kacang tanah pada limbah cair terutama pada limbah yang mengandung logam $\mathrm{Cu}$ (II) agar dapat mengurangi pencemaran logam pada lingkungan air, 3)perlu dilakukan aktivasi adsorben serbuk kulit kacang tanah, agar hasil serapan terhadap logam lebih optimum, 4)perlu dilakukan penelitian lebih lanjut mengenai adsorbsi ion logam $\mathrm{Cu}(\mathrm{II})$ dengan variasi yang lain, misalnya waktu kontak, massa adsorben, 5)perlu dilakukan penelitian lebih lanjut mengenai pengaruh penambahan ion $\mathrm{Cr}(\mathrm{VI})$ terhadap serapan ion $\mathrm{Cu}(\mathrm{II})$ dengan variasi lain, misalnya variasi konsentrasi $\mathrm{Cr}(\mathrm{VI})$.

\section{DAFTAR PUSTAKA}

Cahyono, D. dan Damayanti,A. (2007). Studi Kemampuan Khitosan Sebagai Biosorben Logam Berat (Pb) Dalam Air Limbah Dengan Variasi pH Awal. Makalah Seminar Nasional Manajemen Teknologi III. Program Studi MMT-ITS. Surabaya.

Johnson, T.A., Jain, $\mathrm{N}$ dan Prasad,S (2008). Agricultural and agro-processing wastes as low cost adsorbents for metal removal from waste water. Journal of Scientific \& Industrial Research, 67, 647-658.

Palar, H. (1994). Pencemaran dan Toksologi Logam Berat. Jakarta: Rineka Cipta.

Peraturan Daerah. (2012). Baku Mutu Air Limbah Untuk Kegiatan Industri. Jawa Tengah.

Periasamy, K., Srinivasan, K., dan Murugan, P.K. (1993). Studies on chromium (VI) removal by activated groundnut husk carbon. Indian J. Environ. Health 33, 433-439.

Qaiser, S., Saleemi, A. R., \& Umar, M. (2009). Biosorption of lead (II) and chromium (VI) on groundnut hull: Equilibrium, kinetics and thermodynamics study. Electronic Journal of Biotechnology, 12(4), 3-4.

Saleh, N. (2011). Karakteristik dan Pengaruh Ion $\mathrm{Ca}^{2+}$ pada Adsorpsi Ion Bikromat oleh Humin. Jurnal Penelitian Sains, 14(2), 22-27.

Sastrohamidjojo., H. (2011). Spektroskopi. Yogyakarta: Liberty.

Sivaprakash, B., Rajamohan, N., \& Sadhik, A. M. (2010). Batch And Column Sorption Of Heavy Metal From Aqueous Solution Using A Marine Alga Sargassum Tenerrimum. Int J Chem Tech Res, 2(1), 155-162. 
Sukardjo. (2002). Kimia Fisika. Jakarta: Rineka Cipta.

Sutamihardja, R.T.M., Adnan, K., \& H.S. Sanusi. (1982). Perairan Teluk Jakarta Ditinjau dari Tingkat Pencemarannya. Bogor. Sekolah Pascasarjana. Institut Pertanian Bogor.

Yantri N, K. (1998). Pemanfaatan Jerami Padi (Oryza Sativa) Sebagai Bahan Penyerap Ion $\mathrm{Cu}^{2+}, \mathrm{Cd}^{2+}$ Dan $\mathrm{Pb}^{2+} \mathrm{Pada}$ Limbah Pencelupan Perusahaan Garmen. Skripsi. PSP Kimia Jurusan MIPA. STKIP Negeri Singar. 